\title{
First Case Of SAR-Coronavirus-2 Sequencing In The Cerebrospinal Fluid Of A Patient With Suspected CNS Demyelinating Disease
}

Renan Domingues ( $\nabla$ renan.domingues@senneliquor.com.br)

Senne Liquor Diagnóstico https://orcid.org/0000-0002-6058-7937

Maria Cássia Mendes-Correa

Virology Section (LIM-52), Instituto de Medicina Tropical, Universidade de São Paulo, SP https://orcid.org/0000-0001-5655-8108

\section{Fernando Brunale Vilela de Moura Leite}

Senne Liquor Diagnóstico

\section{Ester Cerdeira Sabino}

Instituto de Medicina Tropical de São Paulo, SP https://orcid.org/0000-0003-2623-5126

\section{Ingra M Claro}

Instituto de Medicina Tropical de São Paulo, SP

\section{Noely Evangelista Ferreira}

Instituto de Medicina Tropical de São Paulo, SP

\section{Camila Malta Romano}

Instituto de Medicina Tropical de São Paulo, SP

Jaqueline Goes de Jesus

Instituto de Medicina Tropical de São Paulo, SP

\section{Daniel Wagner de Castro Lima Santos}

Rede D’Or, Hospital São Luiz Jabaquara, São Paulo, SP

Diego Zanotti Salarini

Rede D'Or, Hospital São Luiz Jabaquara, São Paulo, SP

\section{Carlos Senne}

Senne Liquor Diagnóstico

\section{Case Report}

Keywords: COVID-19, SARS-COV-2, Clinically Isolated Syndrome, Cerebrospinal Fluid

Posted Date: May 29th, 2020

DOl: https://doi.org/10.21203/rs.3.rs-31801/v1 
License: (c) (i) This work is licensed under a Creative Commons Attribution 4.0 International License. Read Full License 


\section{Abstract}

The association between coronaviruses and central nervous system (CNS) demyelinating lesions has been previously shown. However, no case has been described of an association between the novel coronavirus (SARS-COV-2) and CNS demyelinating disease so far. SARS-COV-2 was previously detected in cerebrospinal fluid (CSF) sample of a patient with encephalitis. However, the virus identity was not confirmed by deep sequencing of SARS-COV-2 detected in the CSF. Here, we report a case of a patient with mild respiratory symptoms and neurological manifestations compatible with Clinically Isolated Syndrome. The viral genome of SARS-COV-2 was detected and sequenced in CSF with 99.74 to 100\% similarity between the patient virus and worldwide sequences. This report suggests a possible association of SARS COV-2 infection with neurological symptoms of demyelinating disease, even in the absence of relevant upper respiratory tract infection signs.

\section{Background}

The novel coronavirus (SARS-COV-2) is associated with respiratory symptoms. There have been reports of COVID-19 associated neurological manifestations. The viral genome was demonstrated by RT-PCR technique in cerebrospinal fluid sample (CSF), suggesting that the virus has the ability to infect central nervous system (CNS) ${ }^{1}$. The association between other coronaviruses and CNS demyelinating lesions has been studied ${ }^{2,3}$. However, no case has been described of an association between SARS-COV-2 and CNS demyelinating disease so far.

\section{Case Report}

A 42 year-old patient, resident in São Paulo, sought neurological consultation due to paresthesias of the left upper limb, later progressing to left hemithorax and hemiface.

Upon neurological examination, she had only hypoesthesia in the aforementioned regions. The patient also had respiratory symptoms without fever for 3 weeks. RT PCR for SARS-COV-2 of nasal and pharyngeal swab and cerebrospinal fluid (CSF) was carried out. Specific SARS-COV-2 RNA primers and probe directed to RDRP-2 gene described by WHO (Charité, Berlim) were used. A control CSF examination was carried out sixteen days later.

Blood cell counts, transaminases, bilirubin, CPK, coagulogram, electrolytes, renal function, C-reactive protein were all normal. CSF analysis showed $1 \mathrm{WBC} / \mathrm{mm} 3$, protein of $32 \mathrm{mg} / \mathrm{dl}$, and glucose of 68 $\mathrm{mg} / \mathrm{dl}$. No CSF oligoclonal bands were demonstrated. Brain magnetic resonance imaging (MRI) was normal. Cervical MRI is shown in Figure 1. The clinical diagnostic hypothesis was a low risk Clinically Isolated Syndrome (CIS). RT-PCR for SARS-COV-2 was positive in the first CSF sample, negative in nasal and pharyngeal samples, and negative in control CSF.

To confirm the identity of the virus in CSF identified in the CSF sample we deep sequenced the material using the MinION platform from Oxford Nanopore technology as described in 
(https://www.protocols.io/view/ncov-2019 sequencingprotocol-bbmuik6w). Reads were mapped against MN908947.3 reference genome using CLC genomic workbench v.16 (Qiagen). Due to the low viral load present on the CSF, a full genome consensus was not obtained. Regions having the better coverage of the genome ( $>200)$ were used to the analysis. Therefore, two fragments from ORF1a were obtained and concatenated resulting in a 1580 nucleotide-long sequence that was multiple-aligned together to 200 worldwide representative SARSCOV-2 reference genomes (available at GISAID). An identity matrix was generated and revealed 99.74 to $100 \%$ similarity between the patient virus and worldwide sequences. No additional regions from the patients SARS-COV-2 genome other than the used for similarity analysis were obtained with enough quality to allow a more detailed investigation on putative nucleotide or aminoacid particular substitutions. The patient had full recovery after 3 weeks. Institutional Ethical Board approval and written consent were obtained.

\section{Discussion}

Here, we report a case of SARS-COV-2 infection with a clinical presentation compatible with CIS4. To the best of our knowledge CNS demyelinating disease has not been associated with COVID-19 so far; however, other coronaviruses were associated with CNS demyelinating autoimmune diseases, including MS exacerbations ${ }^{5}$ and autoreactive $T$ cells able to recognize myelin antigens ${ }^{6,7}$.

One single report describes CSF positivity for SARS-COV-2 by RT-PCR technique ${ }^{1}$. To the best of our knowledge this is the first report to confirm the identity of SARS-COV-2 in CSF with deep sequencing. There are multiple proposed mechanisms for SARS-COV-2 entry into the CNS. As already studied for other coronaviruses, SARS-COV-2 could move via olfactory nerve ${ }^{8}$ or by hematogenous spread ${ }^{9}$. The actual neuropathogenic role of SARS-COV-2 after having access to CNS remains to be established.

This case report suggests a possible association between CNS focal symptoms compatible with demyelinating disease and SARS-COV-2 infection. This report should alert clinicians to this possible association, even in the absence of relevant upper respiratory tract infection signs.

\section{Declarations}

On behalf of all authors, the corresponding author states that there is no conflict of interest.

The present study "FIRST CASE OF SARS-CORONAVIRUS-2 SEQUENCING IN THE CEREBROSPINAL FLUID OF A PATIENT WITH SUSPECTED CNS DEMYELINATING DISEASE" was approved by the Research Ethics Committee of the Hospital das Clínicas (Cappesq), São Paulo University Medical School, with the number CAAE 67203417.0.0000.0068.

Informed consent form was obtained from the patient.

We declare that we take full responsibility for the data, the analyses and interpretation. Each author has 
participated sufficiently in the work to take responsibility for the content. The above named study was not supported by a corporate sponsor.

\section{References}

1) Moriguchi T, Harii N, Goto J, Harada D, Sugawara H, Takamino J, Ueno M, Sakata H, Kondo K, Myose $N$, Nakao A, Takeda M, Haro H, Inoue O, Suzuki-Inoue K, Kubokawa K, Ogihara S, Sasaki T, Kinouchi H, Kojin H, Ito M, Onishi H, Shimizu T, Sasaki Y, Enomoto N, Ishihara H, Furuya S, Yamamoto T, Shimada S (2020) A first case of meningitis/encephalitis associated with SARS-Coronavirus-2. Int J Infect Dis 94:55-58. https://doi: 10.1016/j.jijid.2020.03.062.

2) Dessau RB, Lisby G, Frederiksen JL (2001) Coronaviruses in brain tissue frompatients with multiple sclerosis. Acta Neuropathol 2001;101(6):601-4. PMC7086566.

3) Arbour N, Côté G, Lachance C, Tardieu M, Cashman NR, Talbot PJ (1999) Acute and persistent infection of human neural cell lines by human coronavirus OC43. J Virol 73(4):3338-50. PMC104098.

4) Thompson AJ, Banwell BL, Barkhof F, Carroll WM, Coetzee T, Comi G, Correale J, Fazekas F, Filippi M, Freedman MS, Fujihara K, Galetta SL, Hartung HP, Kappos L, Lublin FD, Marrie RA, Miller AE, Miller DH, Montalban X, Mowry EM, Sorensen PS, Tintoré M, Traboulsee AL, Trojano M, Uitdehaag BMJ, Vukusic S, Waubant E, Weinshenker BG, Reingold SC, Cohen JA. Diagnosis of multiple sclerosis: 2017 revisions of the McDonald criteria (2008) Lancet Neurol;17(2):162-173. https://doi: 10.1016/S1474-4422(17)30470-2.

5) Hovanec DL, Flanagan TD (1983) Detection of antibodies to human coronaviruses 229E and OC43 in the sera of multiple sclerosis patients and normal subjects. Infect Immun 41(1):426-9. PMC264797.

6) Boucher A, Desforges M, Duquette P, Talbot PJ (2007) Long-term human coronavirus-myelin crossreactive T-cell clones derived from multiple sclerosis patients. Clin Immunol 123(3):258-67. PMC7106099.

7) Desforges M, Le Coupanec A, Stodola JK, Meessen-Pinard M, Talbot PJ (2014) Human coronaviruses: viral and cellular factors involved in neuroinvasiveness and neuropathogenesis. Virus Res 194:145-58. https://doi:10.1016/j.virusres.2014.09.011. 8) Netland J, Meyerholz DK, Moore S, Cassell M, Perlman S (2008) Severe acute respiratory syndrome coronavirus infection causes neuronal death in the absence of encephalitis in mice transgenic for human ACE2. J Virol 82(15):7264- 7275.

https://doi:10.1128/JVI.00737-08

9) Gu J, Gong E, Zhang B, Zheng J, Gao Z, Zhong Y, Zou W, Zhan J, Wang S, Xie Z, Zhuang H, Wu B, Zhong H, Shao H, Fang W, Gao D, Pei F, Li X, He Z, Xu D, Shi X, Anderson VM, Leong AS (2005) Multiple organ infection and the pathogenesis of SARS. J Exp Med;202(3):415-24. https:// doi:10.1084/jem.20050828

\section{Figures}




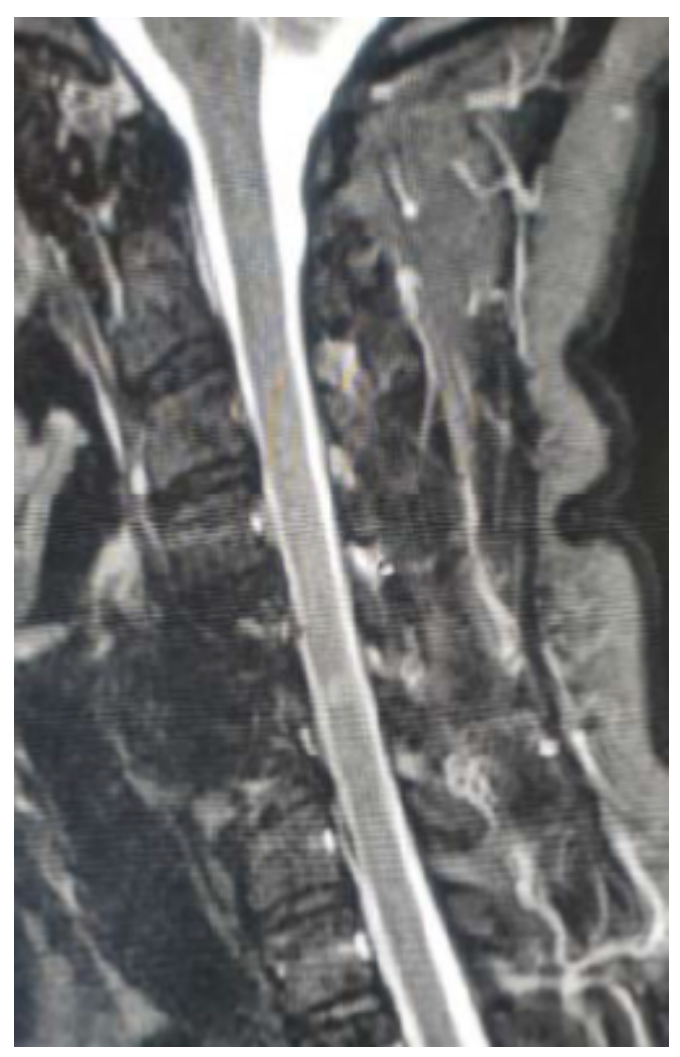

\section{Figure 1}

Cervical spinal cord with a small left lateral ventral lesion with T2 / STIR hypersignal, without mass effect, without gadolinium enhancement, measuring about $0.4 \mathrm{~cm}$ in its sagittal plane. 